\title{
Computer Courses in Finnish Schools, 1980-1995
}

\author{
Petri Saarikoski \\ Digital Culture, Degree Program in Cultural Production and Landscape Studies \\ PL 124, 28101 University Consortium of Pori, Finland \\ petsaariautu.fi
}

\begin{abstract}
The early history of computers in Finnish schools occurred during the period 1978-1995. In high schools, courses were officially included in the curricula in 1982, while at the upper level of comprehensive school, computer courses started in 1987. This paper describes and analyzes the challenges and results of the first wave of computer education in the Finnish school system.
\end{abstract}

Keywords: Comprehensive schools, computer clubs, computer courses, computer literacy, Finland, high schools, history of computer education.

\section{Introduction}

"Discussion about the computerization of our school system has mainly been dominated by computer consultants and the computer industry. This has been affected by the myth of the information society. It is regrettable that, in this way, parents and teachers have suddenly and sadly lost their self-respect."

The above sentences were included at the start of a research publication [1] written by Jarkko Alajääski, Senior Lecturer of Didactics of Mathematics. The work, which was published in the spring of 1987, strongly criticized the way in which computers and information technology had so far been introduced into schools. In the late 1980s, there were relatively few academic studies available about the use of computers in Finnish schools. Some researchers had collected data and material from high schools where computer teaching (more commonly known in the early 1980s as "teaching of Automatic Data Processing" or more simply "ADP-teaching") had started in the 1980s. The results had mainly been embarrassing; high school students and teachers had declared that "ADP-teaching" did not work as the National Board of Education had planned it [2].

In media publicity, the computerization of schools was more commonly associated with "the computer literacy project." I have studied the computerization of schools in a couple of publications and partly in my doctoral thesis $[3,4,2]$. In this article, I examine how the adoption of computers started in schools during 1980-1995. What were the politics of this computerization project? In what ways were the interaction between schools and computer clubs established? It is also important to study the collaboration of teachers and pupils. What was the role of the ordinary pupil, seen as an integral part of the computer culture, which was already taking shape? 


\section{Background of the Early Computer Courses}

The teaching of data processing and information technology began in the Finnish universities during the 1960s, and some basic courses were available in some schools and institutes in the late 1960s and early 1970s. In Finland, this was combined with the educational and do-it-yourself aspects of IT-learning. Early courses were usually joint ventures between local schools, universities, and computer companies. This kind of activity started in major cities, especially in the metropolitan area. Sources have indicated that Tapiola co-educational school in Espoo offered ADP-courses already in 1965. This particular school was well known for its reformist curriculum and openmindedness towards the use of new technology. During these first experimental courses, pupils had the opportunity to learn the basics of programming. After their graduation, some of the more talented pupils started to study ADP at university $[5,6]$.

Computers and information technology, more generally, still had no official status in the Finnish school system during the 1970s. ADP-teaching was only available in some special courses and in unofficial computer clubs founded by some far-sighted teachers. In fact, during the 1970s and early 1980s, ADP-teaching and the hobby of microcomputers were socially and culturally very close to each other. However, things had begun to change from the mid-1970s onwards. Finland was in a deep economic depression during the late 1970s. Traditional heavy industry was in crisis and companies were rapidly seeking solutions for production problems from computerization, the use of electronics, and industrial automation. Economic life and society was clearly changing. The policy of the information society was established by the state and the usage of information technology was seen as part of everyday life. This also meant fundamental challenges for the Finnish school system [7, 4].

The consultative committee for the development of ADP in Finnish society funded by Sitra, the Finnish Innovation Fund - started a major research project in the spring of 1977, in which the challenges and opportunities of IT in schools were studied. The ulterior motive of this project was the formalization of ADP for the Finnish school system. The research report published in 1978 indicated that there were indeed many challenges; very few schools had computers or any other ADPinfrastructure available. When the situation was compared to other Nordic countries, the results showed that Finland's readiness for ADP-education in schools was weak. As a conclusion, the report proposed that drastic measures were necessary before the first ADP-courses could be started. Primarily, this meant that schools were obligated to purchase computers and other hardware. Computer training should also be arranged for the teachers. According to the report, this reform was to be first started in high schools and then in comprehensive schools. The proposal argued that from the economic point of view, the fast computerization of high schools was realistic, because in doing so learning results would be quickly utilized $[8,9]$.

The early 1980s was a crucial turning point for the Finnish school system. The reform of the comprehensive school system, started in the 1970s, was already completed, and the computerization of schools, initiated by the government, was a major addition to the whole school system. This project was, in fact, a combination of separate IT-projects that took place during the 1980s. The basic goal of each of these projects was the foundation and maintenance of IT-infrastructure for the Finnish educational sector. These projects had a clear and understandable connection to other 
similar projects that had started in the 1970s and 1980s in Europe (for example, in Britain, France, and the Nordic countries). The concept of "computer literacy" was very popular during the 1980 s and it was mostly linked to the domestication of the home computer. It had strong connections to the use of home computers during leisure time, but also to the computerization of schools. A typical early adopter of computer literacy was the computer hobbyist. The concept became common during the late 1970s, but it gained more popularity in the media during the early 1980s. The whole concept, and especially its media exposure, was the counterpart of a similar kind of public discussion that was going on in Europe at the same time. The bestknown example was Britain's "The Computer Literacy Project," started by the Ministry of Education in the late 1970s and early 1980s [10,11].

In Finland, the concept of "literacy" has a very strong connection to the emergence of the welfare state after World War II. Free education provided by the state became the very cornerstone of Finnish society. Therefore, in Finland, "literacy" was both a privilege and an obligation at the same time. This evocative concept was also analyzed in the media by a series of experts, who underlined that in coming decades the knowledge and mastery of computers was to become a strong part of general education. This marks the point at which computers came to be seen as a tool in the education of youth and children, making it possible for them to acquire the basics of computer literacy that were to be so valued in the future. This is, of course, only a generalization. Families typically bought their first home computers as a leisure tool for technically-oriented boys. On the other hand, the early 1980s was a period characterized by a strengthening of the optimistic, symbolic meanings associated with home computers $[12,2]$. The concept of computer literacy has similarities to the concept of digital literacy, which became popular during the first decade of the twenty-first century [13].

In addition, the concept of computer literacy linked closely to the emergence of the microcomputer hobby and the opening of home computer markets during the early 1980s. Unofficial computer clubs in schools were also part of this development. These clubs operated like earlier technically oriented clubs founded by radio amateurs and electronics enthusiasts [3]. The importance of these clubs was also noticed in reports published by the Ministry of Education. Such clubs became important staging posts in some schools before the official introduction of ADP-courses.

The official start of computerization in schools offered new markets for the computer industry. Computer systems, designed for educational purposes and home computing, were also manufactured and designed in the Nordic countries. Perhaps the best-known example was the ABC80 microcomputer engineered by the Swedish corporation Dataindustrier $\mathrm{AB}$ (DIAB) and manufactured by Luxor. The growth of the educational computer market was also noticed in Finland, and sources indicate that the Finnish IT-industry was also interested in starting its own serial production of home computers. Nokia became the most successful manufacturer of microcomputers in Finland during the 1980s and early 1990s. The Nokia MikroMikko series was sold to industry, schools, and households [14, 3].

In Finland, the number of computer systems ordered by schools increased slowly, but in 1980 and 1981, computerization began to escalate, when more state aid was available. In 1979, one high school out of ten had purchased computers and associated peripherals, but in 1981, almost 33 percent of high schools had some sort of 
ADP-infrastructure. Furthermore, in high schools, ADP-courses were officially included in the curricula in 1982 and, during the autumn term of the same year, ADPcourses were arranged in 320 high schools, which comprised almost 70 percent of all upper secondary schools. During the following spring term, almost 87 percent of all high schools could arrange ADP-courses. In the autumn term of 1983, ADP-teaching was offered in practically every Finnish high school. The National Board of Education calculated that about one third of upper secondary students took a computer course as a free elective [2, 9].

The most popular computers used in high schools during these years were ABC80, Apple II, Nokia MikroMikko, and AMC-100, which the National Board of Education recommended. The machines usually operated with $32-128 \mathrm{kB}$ memory and the most common operating system was CP/M, provided by Digital Research. Furthermore, the most typical computer system was AMC-100, manufactured by Finnish Auditek. One AMC-100 classroom system consisted of one minicomputer for the teacher, six terminals for pupils, educational software, and associated peripherals, which constituted extremely expensive investments for high schools [12, 9].

\section{Finnish Model for Computer Education}

The ADP-education of institute members had many problems right from the start. The main problem was that in the 1980s, educational software support was very weak. There was also a lack of decent course material and difficulties with teacher training. In most of the cases, teachers had no other alternative than to start courses with the programming exercises. BASIC programming language was widely criticized for dominating the computer curriculum. Many IT-experts criticized these courses for having no real value in working life, where the need for skilled ADP-workers was growing all the time. These problems were also noticed by the Ministry of Education, but the lack of extra resources and relatively bureaucratic policymaking, led to the situation in which most of the problems remained unsolved [15]. ADP-courses were mostly successful if teachers were motivated and had taken part in the education provided in computer clubs. Most of these teachers were also computer hobbyists who also quickly learned that it was more effective and affordable to buy home computers for classrooms. For example, Commodore Vic-20 and especially Commodore 64, both very successful home computers in computer clubs, were purchased for some schools. In this way, computer clubs were also established in some comprehensive schools [16-19].

During the 1980s, a characteristic of the Finnish "computer education model" was that computers did not belong to the lower level of the comprehensive school. In reports and memoranda produced by the Ministry of Education, there are still references to experts who recommended that some sort of ADP-education should be available at the lower level of the comprehensive school. However, these recommendations were mostly ignored when plans for the computerization of the upper level of comprehensive schools began in 1984 [20,6].

On 12 October 1984, ADP was officially accepted as a free elective in the new reform order for the Finnish comprehensive school (which was roughly translated in the late 1980s simply as "Computer course"). The curriculum for these new computer 
courses was mainly planned by the "Tietokone opetuksessa" (Computing at School) working committee. The first draft was presented in the spring of 1985. It had several interesting features, for example, the working committee insisted that the mistakes made in high schools should be avoided. This meant the reduction of the importance of programming languages. The draft included several modules: the basics of computer use, information networks, programming, and computer-aided education. The latter module included the idea that teachers could use computer software in drawing and language courses. BASIC was still considered a good option for the programming module, but the committee recommended that simpler LOGO programming language should be included as an alternative. The most ambitious idea of these first drafts was that in future years all school courses could be computeraided, the long-term elaboration of which was left open $[2,6]$.

During 1985-1987, the state gave special funding to ten schools where computers had been partly used in unofficial computer clubs. The best-known examples include the computer club of Herttoniemi Primary School (started in 1984) from Helsinki and the computer club of Uomarinne Primary School (started in 1985) from Vantaa (Fig.1). Computer courses officially began at the upper level of comprehensive school during the autumn term of 1987 (eighth grade) and the autumn term of 1988 (ninth grade). 20 percent of municipalities postponed the start for one year and, according to some statistics, about 60 percent of pupils did choose the computer course during 1988-1989. The computerization of Finnish society had clearly put some demands on the Finnish school system. The first waves of the home computer boom were already starting to diminish in 1985-1987, but PC-microcomputers, more common in business use, had clearly gained some foothold in consumer markets. In this way, PC, an industry standard, was slowly but steadily becoming the most common computer platform in households and schools. The National Board of Education decided that schools should primarily purchase MS-DOS -compatible PCs, and by the spring of 1988, some eight thousand microcomputers were available in schools, although only half were PCs. These new instructions were criticized because PC-compatible microcomputers were usually very expensive. Schools had already saved money when they had purchased affordable home computers. It is interesting that this politically and technically motivated decision also helped Nokia to increase the sale of MikroMikko computers to schools [21-25,6].

The time schedule for the launch of computer teaching in comprehensive schools was extremely tight and criticism of the politics of computerization was growing in 1987, as Jarkko Alajääski's study had shown. Some of the teachers and researchers were very skeptical about the successful embrace of the new computer education program [1]. Insufficient teacher training was a major problem; most of the teachers started their first computer course after only one week of training. Pekka Lehtiö, who was involved with the Computing at School working committee, had later stated in an interview that the National Board of Education had a clear tendency to statistically show that there were more and more computers in schools and the Finnish school system was therefore being updated to meet the demands of the information society. On the other hand, little attention was being paid to the implementation of the curriculum itself [22]. This once again created problems at the grass root level of computer education. 


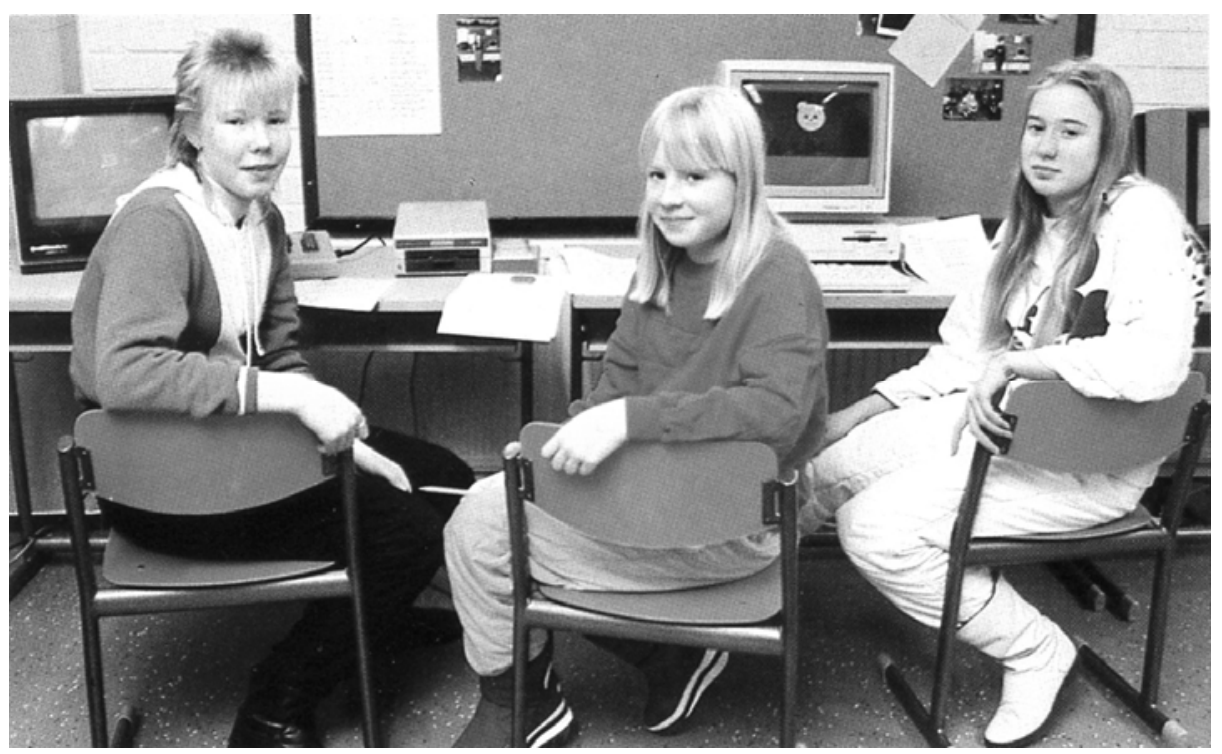

Fig. 1. Sixth grade pupils, from Uomarinne primary school in Vantaa, using Commodore 64 at their school's computer club (spring 1987). Courtesy of A-lehdet.

During the late 1980s, the lack of decent educational software and course material was a continuous problem. Once again, programming exercises played an important part in most of the computer courses. Some of the problems can be explained by teaching politics; computer courses were mostly given to the teachers of mathematics and physics. The Trade Union mostly backed this policy for Teachers of Mathematics and Physics ("Matemaattisten Aineiden Opettajien Liito," MAOL) [22]. This might have given a boost to the mathematically oriented "teaching philosophy;" if computer literacy was the essential ability of the information society, then programming was its official language.

The expensive license fees can partly explain the lack of decent software. Programming languages remained in the curriculum most of the 1990s, but were slowly substituted for the computer-aided teaching methods. This was also a time of growth for educational software systems, primarily due to the advent of more affordable computers and the Internet. For example, pupils could try out Visual Basic programming environments later, in connection with their education. Pascal programming language has also been used in the illustration of programming principles. This education has undoubtedly been particularly useful for the technical and mathematical oriented high school students. The technical simplicity of LOGO programming language has also extended its life cycle. In Finland, LOGO is still occasionally used in teacher education [2].

Although computer courses were less technically oriented in the late 1980s and early 1990s than in the early 1980s, sources indicate that learning results were controversial. While some of the pupils had difficulties in following the teaching because they had absolutely no foreknowledge of computer use, some of the computer hobbyists, typically boys, could feel that course exercises were too easy. In 
questionnaires and interviews collected some fifteen years later, informants criticized these computer courses. Some of them thought that the teachers had not enough experience and that the pupils knew more about the subject than their instructors [26]. These levels of difference between user generations and groups had already been common in the 1960s and 1970s, when the first computer courses became available. There are also examples where informants criticized the authority of teachers; pupils were instructed to strictly follow the course exercises and not to try anything independently. On the other hand, there are also a number of neutral examples where computer courses in schools were classified as the first steps towards more advanced computer education. When teachers were motivated and pupils had the ability to cooperate, learning results were even better. The usability of computer courses improved when word processing, spreadsheets, computer graphics, music, and even games became more common in the curriculum during the 1990s. During these years, computers were also more widely introduced into the lower level of comprehensive school [27, 2]. Despite advances in computer education, the challenges and problems continued in the 1990s. The economic depression in Finland had a severe negative effect on the Finnish school system. During 1991-1995, schools had less money for the purchase of new computers, associated peripherals, and software. A major turning point occurred in 1995 when the government started to intensify information society programs [28].

During these years, the emergence of information networks began to increase. Already in the late 1980s, some pupils and students were also active users of information networks, such as BBS (Bulletin Board System) and several other systems. BBS networks were especially important in Finland before the country was connected to the Internet in the late 1980s. This tradition also continued in the 1990s, when the culture of information networks began to spread. In universities and other institutions, local networks were important points of connection for hobbyists, students, and professionals of information technology. These socially constructed networks led to more benefits and more use. The short cultural history of this development includes the communal spirit and mutual support of USENET, BBS, and the early Internet, in general, and leads into the Open Source movement as its contemporary successor [4].

\section{Conclusion}

In the late 1980s, the prominence of information technology was contradictory in the Finnish society. The domestication of microcomputers was more clearly regarded as an integral part of the Finnish society, but there was still a wide discussion about the purpose and usability of information technology. The early years of computer literacy and information technology in Finnish schools were challenging in many ways. Computerization started hastily and led to several problems. For policymakers, it was easy to show that the computerization project was advancing, because computer hardware was being steadily purchased for schools. Nevertheless, there were indications that too little attention was being paid to the implementation of the curriculum itself. Insufficient teacher training was one of the main problems, and for some pupils, parts of the curriculum modules also had an orientation that was too 
technical. In addition, the programming language was widely criticized for dominating the curriculum. Still, for many pupils, these initial computer courses were the first opportunity to learn the basics of computing, when the domestication of computers was in its early stages.

On the other hand, computer hobbyists could feel that courses were too simple or they had other motivation problems regarding the authoritarian teacher. In recent studies [4], I have noticed that some of the "success stories of computer education" have links to the unofficial computer clubs. During the 1980s, these clubs also had links to the culture of computer hobbyists, who created a range of subcultures, where different kinds of communities began to emerge. Networks of these communities formed a very strong social base for the emergence of the computer culture of the 1990s.

\section{References}

1. Alajääski, J.: Tietokoneopetus peruskoulun ala-asteella: Johdanto ja käsitteitä. Jatkoopiskeluun liittyvä tutkielma. Turun yliopiston kasvatustieteellinen tiedekunta, Turku (1987)

2. Saarikoski P.: Koneen ja koulun ensikohtaaminen Suomalaisen atk-koulutuksen varhaisvaiheet peruskoulussa ja lukiossa. Tekniikan Waiheita, (3) (2006)

3. Saarikoski, P.: Koneen lumo. Mikrotietokoneharrastus Suomessa 1970-luvulta 1990-luvun puoliväliin. (The Lure of the Machine. The Personal Computer Interest in Finland from the 1970s to the mid-1990s) Väitöskirja, yleinen historia, Turun yliopisto (Doctoral thesis, Department of History, general history, University of Turku, October 2004). Jyväskylän nykykulttuurin tutkimuskeskuksen julkaisuja 83 (publisher: The Research Centre for Contemporary Culture). Jyväskylä (2004)

4. Saarikoski, P., Suominen, J., Turtiainen, R., Östman, S.: FUNETIsta Facebookiin. Internetin kulttuurihistoria. (From FUNET to Facebook: Cultural History of Internet in Finland), Gaudeamus, Helsinki (2009)

5. Saarikoski P.: Koneen lumo, pp. 44-45 (2004)

6. Tietokone opetuksessa -projektin (TOP) mietintö. Tietotekniikan integroiminen kouluopetukseen. Tulosten arviointi ja jatkotoimet. Opetusministeriö. Helsinki Liite 1, 2 (1989)

7. Saarikoski P.: Koneen lumo, pp. 58-59 (2004)

8. Parkkinen, M., Rantanen, J., Valli, T.: Tietokone opetuksessa. Suomen itsenäisyyden Juhlarahasto Sarja A 56, 63-64 (1978)

9. Lukion atk-laitteita ja ohjelmistoja selvittäneen työryhmän (ATLAS) muistio. Kouluhallitus, Helsinki, 5-8 (1982)

10. Haddon, L.: The Roots And Early History of the British Home Computer Market: Origins of the Masculine Micro. Management School Imperial College. University of London, London (1988)

11. Saarikoski P.: Koneen lumo, p. 145 (2004)

12. Tietokone $3 / 91983$

13. Digitaalinen sisältötuotanto - strategiset tavoitteet ja toimintaehdotukset. Opetusministeriö, Sisältötuotantotyöryhmän raportti Helsinki (2002)

14. Radiokauppias, October 28-29 (1981)

15. Saarikoski P.: Koneen lumo, pp. 45-46 (2004) 
16. Kivinen, A.: Taulukkolaskentaohjelma mikrotietokoneen opetuskäytössä. Suomen kasvatustieteellinen aikakauskirja Kasvatus 16(5), 347-352 (1985)

17. Raivola, R.: Uusi informaatioteknologia edellyttää koulun muuttumista. Suomen kasvatustieteellinen aikakauskirja Kasvatus 16(5), 359-366 (1985)

18. Tietokone, February 66-67 (1983)

19. Printti 12, 4 (1986); Printti 14, 9, 26 (1986)

20. Aikuisväestön tietotekniikan peruskoulutus. Tietotekniikan aikuiskoulutuksen suunnitteluryhmän muistio. Opetusministeriön työryhmien muistioita 5, 1-15 (1986)

21. Saarikoski, P.: Koneen lumo, p. 118 (2004)

22. Lehtiö P.: Interview (January 21, 2005)

23. Printti 1,3 (1985) Printti 1,16 (1986) Printti 5, 3 (1986) Printti 4, 16-18 (1987) Printti 19, 16-17 (1987)

24. Opettaja 9, 22-24 (1986) Opettaja 5, 4-5 (1987)

25. Tietokone opetuksessa -projektin (TOP) mietintö, 42-43

26. TIESU-kysely (2003), http: / / kul tmais .utu.fi / tiesu (June 12, 2010)

27. Kajosvaara, J.: Tietotekniikka ala-asteen koulutyössä. Loppuraportti. Opetushallitus, TAKO-projekti 1.1.1990-30.6.1991, Rauma, pp. i-ii (1991)

28. Valtioneuvosto, Suomi tietoyhteiskunnaksi. Kansalliset linjaukset. Edita: Helsinki (1995) 